\title{
MORPHOLOGICAL RESPONSE TO IMPLANTATION OF A POLYPROPYLENE MESH WITH A PRF MEMBRANE IN PATIENTS WITH POSTOPERATIVE VENTRAL HERNIA AND UNDIFFERENTIATED CONNECTIVE TISSUE DYSPLASIA
}

\author{
V. I. Piatnochka, A. M. Prodan \\ I. HORBACHEVSKY TERNOPIL STATE MEDICAL UNIVERSITY, TERNOPIL, UKRAINE
}

\begin{abstract}
Background. Current herniology promotes the widespread usage of mesh implants in the primary treatment and, especially, in the for postoperative ventral hernias.

Objective. The aim of the research was to study the morphological response of the tissues of muscular aponeurotic layer to implantation of a polypropylene mesh with using PRF membrane-enriched platelets in the patients with postoperative ventral hernia and concomitant undifferentiated dysplasia of connective tissues.

Methods. The research involved 98 patients with postoperative ventral hernia, who underwent retro-muscular alogernioplasty by the Sublay technique of implantation of 'light' meshes, and a 'light' polypropylene mesh (PPM) in combination with a platelet-rich fibrin (PRF) membrane. The patients were divided into experimental groups according to the presence of undifferentiated connective tissue dysplasia syndrome.

Results. Microscopic studies carried out after the implantation of a polypropylene mesh with a PRF membrane has proved that structural changes in connective tissues are like those of a polypropylene mesh, but they are less significant. There was a leukocyte infiltration near the mesh material, but its area was small. The enlargement and blood filling of the vessels of microcirculatory channel was a manifestation of the increased vascularization of this area.
\end{abstract}

Conclusions. The usage of a polypropylene mesh in combination with a PRF membrane in the surgical treatment of postoperative ventral hernias reduces inflammatory changes in the tissues significantly and increases the activation of fibroblasts and signs of collagen fibers around the mesh material that is relevant especially for the patients with connective tissue pathology.

KEY WORDS: postoperative ventral hernia; undifferentiated connective tissue dysplasia; polypropylene mesh; PRF membrane.

\section{Introduction}

Contemporary herniology promotes the widespread usage of mesh implants in the primary treatment and, especially, in the postoperative period of ventral hernias. This is supported by the improved methods of surgical treatment and high-quality allotransplants. However, alologernioplasty does not always provides reliability of the surgery $[1,2,3]$. Adequately selected techniques and materials for aloplasty minimize surgical tactical and technical causes of the development of relapse [4]. Therefore, the identification of other objective causes remains relevant. One of these conditions, which can cause a rapid relapse, is a concomitant syndrome of undifferentiated connective tissue dysplasia (UCTD). Such surgi-

Corresponding author: Volodymyr Piatnochka, MD, Ph.D., Associate Professor, Department of Surgery, Institute of Postgraduate Education, I. Horbachevsky Ternopil State Medical University, 1 Maydan Voli, Ternopil 46001, Ukraine.

E-mail: pyatnochkavi@tdmu.edu.ua cal intervention using mesh implants does not always allow achieving the expected result [5].

In our opinion, the study of combined usage of polypropylene mesh with a PRF membrane consisting of fibrin-rich platelets is very interesting $[6,7]$. Biocompatible PRF membranes rich in growth factors stimulate an active growth of new capillaries, improve blood flow, accelerate metabolic processes in tissues, increase collagen formation, hyaluronic acid, reduce inflammatory process in tissues significantly that can positively affect the state of local tissues during implantation of polypropylene meshes in cases of UCTD.

The aim of the research was to study peculiarities of morphological response of the tissues of muscular aponeurotic layer of anterior abdominal wall to implantation of polypropylene mesh with a PRF membrane in the patients with concomitant undifferentiated dysplasia of connective tissues. 


\section{Methods}

98 patients underwent surgery at the premises of the Department of Surgery of Ternopil City Clinical Hospital No. 2 in the period from 2015 to 2017, in the Department of Surgery of the Institute of Postgraduate Education of I. Horbachevsky Ternopil State Medical University. The study involved patients with postoperative ventral hernias. All patients underwent retro-muscular alogernioplasty by the Sublay technique of implantation of a 'light' mesh, the diameter of polypropylene thread $0.12 \mathrm{~mm}$, the thickness $0.40 \mathrm{~mm}$, the specific density $45 \mathrm{~g} / \mathrm{m}^{2}$, and an 'light' polypropylene mesh (PPM) in combination with a platelet-rich fibrin (PRF) membrane. The patients were divided into experimental groups according to the presence of UCTD syndrome

The diagnosis of UCTD syndrome was based on specific phenotypic features of dysplasia (6 and more) according to the international M. J. Glesby phenotypic scale and biochemical markers of connective tissue degradation - a serum oxyproline level (L. Bergman and R. Loxley colorimetric method modifications by M. A. Osadchuk and T. P. Kuznetsova), and cryoglobulins (by the method of N. A. Konstantinova and A. Yu. Kirsanov, 1989). For morphological study of diagnosis of non-specific dysplasia of connective tissue, during the surgery a sampling of the aponeurosis fragments of white abdominal line was carried out near the hernia defect of $0.3 \times 0.3 \mathrm{~cm}$ in size. The fragments of anterior abdominal wall with the implanted mesh were taken in 12 patients for further morphological study following the norms of medical bioethics; the patients were re-operated for other pathology of abdominal cavity.

The tissues were fixed in formalin, paraffin embedded and sectioned according to the standard technique. Serial $5 \mu \mathrm{m}$ sections were stained with hematoxylin \& eosin, bloodtyrosine and examined by light microscopy using Delta Optical microscope. Representative areas of the samples were photographed using $\times 10$ and $\times 20$ lens with SCMOS Digital Camera and ToupView software with different magnification.

\section{Results}

According to the specific phenotypic features of dysplasia and biochemical markers of connective tissue degradation, all patients were divided into 2 groups: with and without UCTD syndrome (Table 1).

Histological studies performed after 'light' PPM implantation have proved that the changes in inflammatory nature are observed around the structure of the mesh. There are lymphocytes, neutrophils, macrophages and separate basophils in the area of leukocyte infiltration. The modified fibroblasts and fibrocytes are present. There are a few fibrous structures that are loose and partially fissured in the intercellular substance. The intensified vasculitis of this site, many vessels of the microcirculatory bed, which are blood-filled (Fig. 1), are evidenced.

The results of histological studies of the area of white abdominal line near the hernial protrusion in the patients with undifferentiated

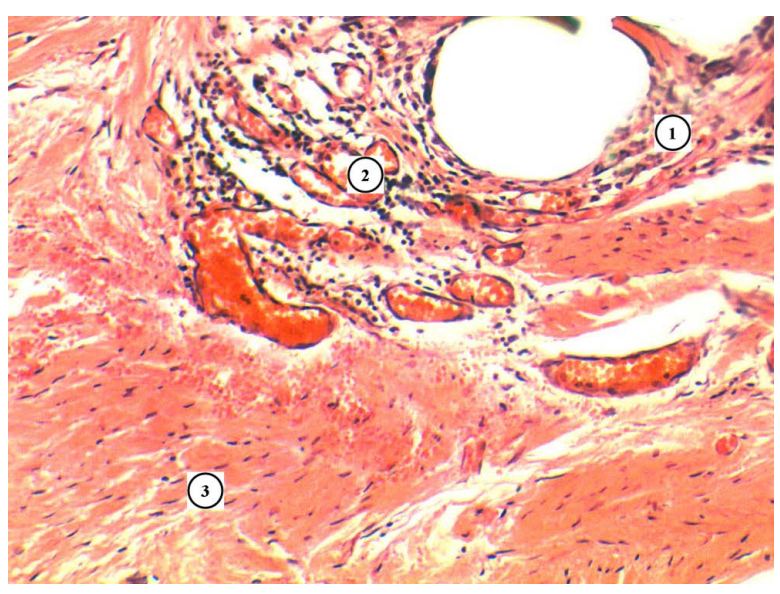

Fig. 1. Microscopic changes in the connective tissues surrounding the implanted material - the polypropylene mesh. Infiltrated area (1), blood vessels (2), muscle tissue (3). H\&E. $\times 100$.

Table 1. Age, sex and type of the implanted mesh division of the examined patients $(\mathrm{M} \pm \mathrm{m})$

\begin{tabular}{|l|c|c|c|c|c|}
\hline \multirow{3}{*}{$\begin{array}{c}\text { Investigated } \\
\text { groups }\end{array}$} & \multicolumn{2}{|c|}{ Types of the implanted mesh } & \multirow{2}{*}{ Patients' } & \multicolumn{2}{c|}{ Patients' sex } \\
\cline { 2 - 3 } \cline { 5 - 6 } & 'Light' PPM & $\begin{array}{c}\text { 'Light' PPM }+ \\
\text { PRF membrane }\end{array}$ & age & Male & Female \\
\hline $\begin{array}{l}\text { Group 1 (n=53) } \\
\text { without UCTD }\end{array}$ & 28 & 25 & $52.2 \pm 0.89$ & $\begin{array}{c}18 \\
(33.96 \%)\end{array}$ & $\begin{array}{c}35 \\
(66.04 \%)\end{array}$ \\
\hline $\begin{array}{l}\text { Group 2 ( } n=45) \\
\text { with UCTD }\end{array}$ & 26 & 19 & $37.4 \pm 1.12$ & $\begin{array}{c}21 \\
(46.67 \%)\end{array}$ & $\begin{array}{c}24 \\
(53.33 \%)\end{array}$ \\
\hline
\end{tabular}


dysplasia of connective tissues have revealed that the collagen and elastic fibers are thinned, with a fine mesh, in different directions and in different spaces. Branching of fibers is evidenced and individual fibers completely lose contact with the main fibers (Fig. 2).

Moderate lymphostiocytic infiltration around the fibers has been observed according to the results of histological study of the area of muscle fibers with a segment of the 'light' polypropylene mesh, which is combined with severe stroma edema, folding of collagen fibers, moderate mucoid edema. There is a mild vascular reaction in the form of a full-bladder capillary combined with perivascular cell infiltration. The swelling spreads to muscle tissues, accompanied by inflammatory infiltration, destruction of fibers and hemorrhagic penetration of tissues (Fig. 3).

Microscopic studies carried out after the implantation of the polypropylene mesh with a PRF membrane have proved that structural

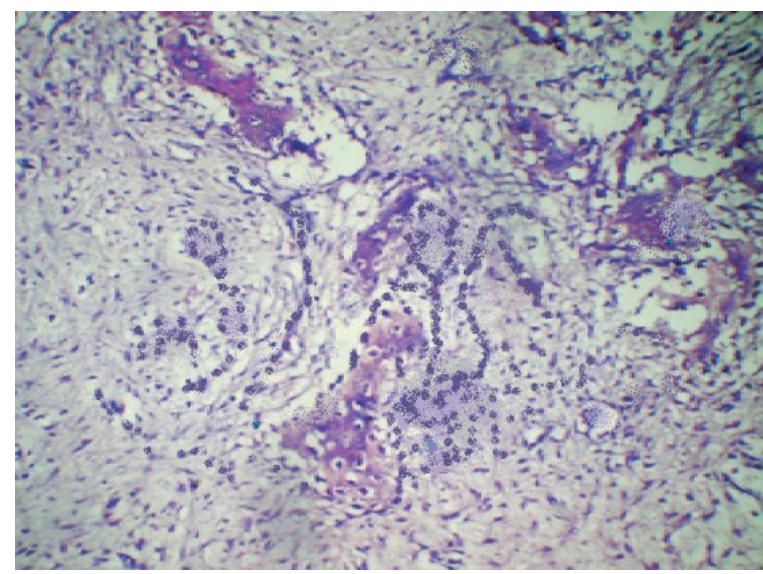

Fig 2. White line of abdomen near the hernial protrusion and UCTD. Blood-tyrosine. $\times 100$.

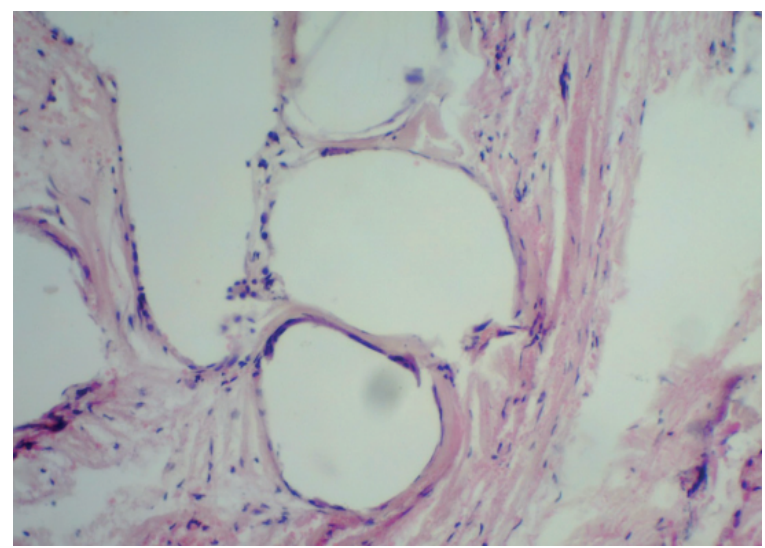

Fig. 3. The area of muscle fiber with a fragment of a polypropylene mesh. Destruction of fibers and hemorrhagic penetration of tissues. H\&E. $\times 100$. changes in connective tissues are similar to those of the polypropylene mesh, but they are less significant. There is leukocyte infiltration near the mesh material, but its space is small. The enlargement and blood filling of the vessels of microcirculatory channel, which is a manifestation of the increased vascularization of this area, is evidenced (Fig. 4).

The formation and concentric arrangement of collagen fibers around the grid structures is revealed. This takes place with the participation of mature fibroblasts. The fragments of mesh fibers are surrounded by collages of collagen fibers, concentrically around the grid structures and arranged at a certain distance. There is a longitudinal shape between fibers with thin fibroblasts, oriented in the direction of the fibers (Fig. 5).

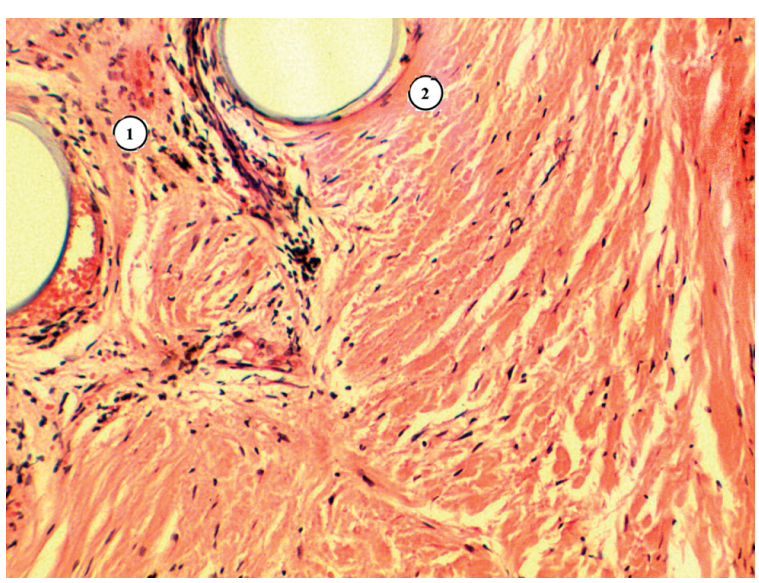

Fig 4. Microscopic changes of the connective tissue surrounding the implanted material - a 'light' polypropylene mesh with a PRF membrane. Infiltrated area (1), collagen fibers (2). H\&E. $\times 100$.

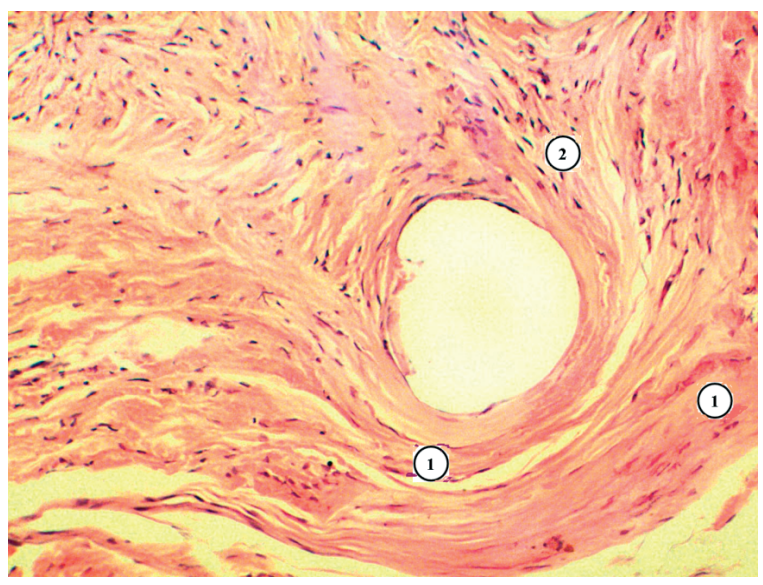

Fig 5. Microscopic changes of the connective tissue of the area surrounding the implanted material - a polypropylene mesh with a PRF membrane. Collagen fibers are located concentrically (1), fibroblasts (2). H\&E. $\times 100$. 


\section{Discussion}

Recurrence after hernia surgery is a considerable clinical problem. Surgical treatment of ventral hernia accounts a hundred methods for today. It means we are still looking for better outcomes and results in postoperative period. The most wanted outcome of surgical treatment of ventral hernias is the absence of relapse for many years. But no one method could provide it today for the results of long prospective observational studies.

Family history, biochemical factors, smoking, method of repair, concomitant bowel surgery, gender, obesity and other factors are very important for hernia recurrence. The research confirms that undifferentiated connective tissue dysplasia is significant factor for abdominal hernia formation $[4,7,8,9]$. Thus, microscopic studies after the implantation of the polypropylene mesh in combination with a PRF membrane have revealed that inflammatory changes in connective tissues with underlying dysplasia are not as significant as in cases of implantation of the polypropylene mesh only. The activation of fibroblasts and signs of formation of fibrous structures around the mesh material have been revealed. This contributes to increased activity of fibroblasts and formation of collagen fibers around the mesh material.

Syndrome of undifferentiated connective tissue dysplasia quite often is masked at common surgical nosology. Its frequency varies and is diagnosed at approximately in one-third of patients of surgical departments. Just because surgeons do not take into account this syndrome mostly, it became the cause of postoperative relapse in each second patient with ventral hernias $[9,10]$. Results of our previous research and histological, morphometric examination, immunological tests of patients underwent the surgery with use of 'light' polypropylene mesh in combination with a platelet-rich fibrin (PRF) membrane showed significantly better outcomes. The rate of recurrences in patients with postoperative ventral hernia, who underwent retro-muscular alogernioplasty was significantly lower [10-12].

\section{Conclusions}

The usage of a polypropylene mesh in combination with a PRF membrane reduces inflammatory tissue changes significantly, increases activation of fibroblasts and signs of collagen fibers around the mesh material, especially in the patients with connective tissue pathology.

The use of PRF membranes of blood plasma stimulates angiogenesis, improves blood flow, accelerates metabolic processes in tissues, formation of collagen that creates favorable conditions for a full integration of the polypropylene mesh into the muscular and aponeurotic layer of the tissues of the anterior abdominal wall, as a result it contributes to reduction of postoperative relapse.

\title{
МОРФОЛОГІЧНА ВІДПОВІДЬ НА ІМПЛАНТАЦІЮ ПОЛІПРОПІЛЕНОВОЇ СІТКИ 3 МЕМБРАНОЮ РRF У ХВОРИХ 3 ПІСЛЯОПЕРАЦИЙНИМИ ВЕНТРАЛЬНИМИ ГРИЖАМИ І НЕДИФЕРЕНЦІЙОВАНОЮ ДИСПЛАЗІЕЮ СПОЛУЧНОЇ ТКАНИНИ
}

\author{
В. І. Пятночка, А. М. Продан \\ ТЕРНОПІЛЬСЬКИЙ ДЕРЖАВНИЙ МЕДИЧНИЙ УНІВЕРСИТЕТ IМЕНI I. Я. ГОРБАЧЕВСЬКОГО, \\ ТЕРНОПIЛЬ, УКРАЇНА
}

Вступ. Cітчасті (mesh) імплантати сьогодні широко використовуються для первинного лікування вентральних гриж, а особливо у випадку розвитку післяопераційних гриж.

Метою дослідження стало вивчення морфологічної реакції тканин м'язового апоневротичного шару на імплантацію поліпропіленової сітки з PRF-мембраною, збагаченою тромбоцитами, у пацієнтів з післяопераційними вентральними грижами та супутньою недиференційованою дисплазією сполучних тканин.

Методи дослідження. У дослідженні брали участь 98 пацієнтів з післяопераційними вентральними грижами, яким проведено герніопластику власнетканинну за типом "sublay" за методикою імплантації "легких" сіток $і$ "легкої» поліпропіленової сітки (РPM) у поєднанні з PRF-мембраною, збагаченою тромбоцитами. Пацієнти були розділені на групи залежно від наявності недиференційованого синдрому дисплазії сполучної тканини. 
Результати. Мікроскопічні дослідження, проведені після імплантації поліпропіленової сітки з PRF мембраною, показали, що в сполучних тканинах розвивалися структурні зміни подібні до таких, як при і при пересадці лише поліпропіленової сітки, але вони були значно менш виражені. Біля сітчастого матеріалу подекуди було зафіксовано інфільтрацію лейкоцитами, але її площа була невеликою. Збільшення і кровонаповнення судин мікроциркуляторного каналу було проявом підвищеної васкуляризаціі цієї ділянки.

Висновки. Використання поліпропіленової сітки у поєднанні з мембраною PRF в хірургічному лікуванні післяопераційних вентральних гриж значно знижує запальні зміни в тканинах і збільщує активацію фібробластів і розвиток колагенових волокон навколо сітчастого матеріалу, що особливо актуально для пацієнтів з патологією сполучної тканини.

КЛЮЧОВІ СЛОВА: післяопераційна вентральна грижа; недиференційована дисплазія сполучної тканини; поліпропіленова сітка; мембрана PRF.

\section{References}

1. Liang MK, Holihan JL, Itani K, Alawadi ZM, Gonzalez JR, Askenasy EP, Ballecer C, Chong HS, Goldblatt MI, Greenberg JA, Harvin JA. Ventral hernia management. Annals of surgery. 2017 Jan 1; 265(1):80-9.

2. Eriksson A, Rosenberg J, Bisgaard T. Surgical treatment for giant incisional hernia: a qualitative systematic review. Hernia. 2014 Feb 1;18(1):31-8.

3. Kingsnorth A. Operation hernia. Hernia, Abstract book, 5th international hernia congress the world hernia celebration. New York, USA. 2012. 16(1). $73 \mathrm{p}$.

4. Winsnes A, Haapamäki MM, Gunnarsson U, Strigård K. Surgical outcome of mesh and suture repair in primary umbilical hernia: postoperative complications and recurrence. Hernia. 2016 Aug 1;20(4):509-16.

5. Fedoseev AV, Chekushin AA. Undifferentiated connective tissue dysplasia how one of possible mechanism of external hernias formation. IP Pavlov Russian Medical Biological Herald. 2010;18(3):125130. [In Russian].

6. Miron RJ, Fujioka-Kobayashi M, Bishara M, Zhang Y, Hernandez M, Choukroun J. Platelet-rich fibrin and soft tissue wound healing: a systematic review. Tissue Engineering Part B: Reviews. 2017 Feb 1;23(1):83-99.

7. Kobayashi E, Flückiger L, Fujioka-Kobayashi M, Sawada K, Sculean A, Schaller B, Miron RJ. Comparative release of growth factors from PRP, PRF, and advan-
ced-PRF. Clinical oral investigations. 2016 Dec 1;20(9):2353-60.

8. Goschinskij VB, Prodan AM, Pjatnichka OZ. Morphological, clinical and biochemical parallels of connective tissue dysfunction in patients with varicose veins of the lower limbs. Scientific Bulletin of Uzhhorod University. Series Medicine. 2014;49(1):5964. [In Ukrainian].

9. Heniford BT, Ross SW, Wormer BA, Walters AL, Lincourt AE, Colavita PD, Kercher KW, Augenstein VA. Preperitoneal ventral hernia repair: a decade long prospective observational study with analysis of 1023 patient outcomes. Annals of Surgery. 2018 Aug.

10. Piatnochka V. Determination of specific symptoms of non-differentiated dysplasia of connective tissue in patients with postoperative ventral hernia with the substantiation of the optimum method of operational intervention and prosthetic type. Hospital Surgery. 2017 Jul;(2):43-9. [In Ukrainian].

11. Piatnochka VI. Morphometric characteristics of changes in the anterior abdominal wall muscles after implantation of polypropylene meshes of different types in experiment. Journal of Education, Health and Sport. 2018; 8(5):325-34.

12. Dziubanovskyy IYa, Piatnochka VI. Complications after alohernioplastics of postoperative ventral hernia: solutions. Ukrainian Journal of Surgery. 2017;(5):79-82. [In Ukrainian]. 